\title{
EMPOWERMENT OF COASTAL WOMEN COMMUNITY OF GAMPONG PUSONG LAMA THROUGH INNOVATION OF MARINE PROCESSED PRODUCTS
}

\author{
Likdanawati ${ }^{1}$, Hamdiah $^{2}$, Cut Putri Mellita ${ }^{3}$ \\ Faculty of Economics and Business, Universitas Malikussaleh \\ E-mail: likdanawati@unimal.ac.id
}

\begin{abstract}
The Lhokseumawe City Government consists of 4 (four) sub-districts, namely Muara Dua District, Muara Satu District, Blang Mangat District and Banda Sakti District. The old Pusong Village is one of the villages located in Banda Sakti District. Gampong Pusong Lama is one of the villages located on the coast of the city of Lhokseumawe, and the average population of Gampong Pusong is whose income depends on the catch of fish. The catch of fishermen is affected by the wind. If the wind is strong then their catch is small and this has an impact on fishermen's income. Under these circumstances, fishermen can only surrender and use a small amount of their past income to meet their daily needs. Fish caught by fishermen have high nutritional and protein content. The fishermen's family members consume the caught fish every day by cooking it as a side dish. Whereas in addition to being cooked as a side dish, fish can also be processed into ready-to-eat food and can increase its economic value. They still have minimal knowledge about the technology of processing fishery products other than being cooked into side dishes. Fishermen's family members, namely fishermen's mothers, have the potential to improve the economic conditions of their families. Given these conditions, it is necessary to make an effort to improve the economy and skills with science and technology. For this reason, it is necessary to make an effort to empower fishing communities, especially women in an effort to increase the income of fishermen's families. The purpose of this Community Service Activity (PKM) is to empower the community by using science and technology to improve the skills and economic income of partners through processing marine products in the form of fish. the processing does not require modern equipment, (2) training and assistance in the manufacture of modern fishery products that are rich in nutrition. (3) product packaging. The result of this activity is the increased knowledge and skills of partners in processing fishery products. The method of carrying out activities is carried out by (1) introducing nutritious modern fishery products whose processing does not require modern equipment, (2) training and assistance in the manufacture of modern fishery products that are rich in nutrition. (3) product packaging. The result of this activity is the increased knowledge and skills of partners in processing fishery products. The method of carrying out activities is carried out by (1) introducing nutritious modern fishery products whose processing does not require modern equipment, (2) training and assistance in the manufacture of modern fishery products that are rich in nutrition. (3) product packaging. The result of this activity is the increased knowledge and skills of partners in processing fishery products.
\end{abstract}

Keywords: Seafood, fish, empowerment, Empek-empek, Kemplang 


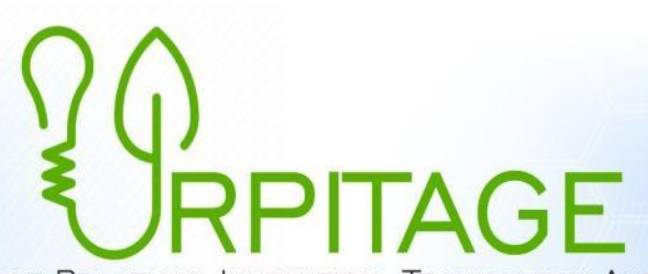

INTERNATIONAL REVIEW OF PRACTICAL INNOVATION, TECHNOLOGY AND GREEN ENERGY

\section{INTRODUCTION}

Lhokseumawe City is one of the cities in Aceh Province, Indonesia. Lhokseumawe City consists of 4 (four) districts, namely Muara Dua District, Muara Satu District, Blang Mangat District and Banda Sakti District. Pusong Lama Village is one of the villages located in Banda Sakti District and is located on the coast of Lhokseumawe City. Coastal communities are people who live and carry out socio-economic activities related to coastal and ocean resources. Thus, in a narrow sense, coastal communities have a fairly high dependence on the potential and conditions of coastal and ocean resources (Fatmasari, 2014).

Common problems faced by fishermen are poverty, limited knowledge for resource management and technology, as well as an active role between outsiders and coastal communities so that they can revive the quality and skills of coastal communities without diminishing their cultural character (Naui and Nikmawatisusanti, 2016). The Pusong Lama community faces complex problems, namely lack of knowledge in fish processing and relatively low income levels because they only depend on their catch to meet their needs, not to mention that fish catches are strongly influenced by wind conditions. If the wind is strong then they can not go to sea. In this condition the fishermen can only surrender and hope that the strong wind will pass soon.

One type of fish caught by fishermen is barracuda fish. Barracuda fish is one type of fishery commodity that has economic value. This fish is often consumed by the public because it has delicious meat and can be processed into various kinds of dishes so that it has a high selling value compared to the selling value that is not processed. Diversification of processed fishery products is important to increase public interest in increasing fish consumption. Fish is a very good food and has the potential to meet the needs of animal protein for the community, it contains protein and omega 3 which functions for the health of the body and the growth of the human brain. Besides being able to be consumed directly, fish meat can also be processed into nuggets, mpekmpek, crackers and somai. This product is a processed product that is quite popular as a favorite food and developed by the fishing community. Given that people generally like food that is practical and fast food and of course it is safe for health.

One of the efforts to increase people's income through fish processing is to diversify products such as empek-empek, nuggets and crackers made from fish. The people of Gampong Pusong Lama need real forms of activity that can build their economy without losing their culture and characteristics. So we need a form of community-based activities. One of the activities that can be carried out is the empowerment of the coastal women of Gampong Pusong Lama through the innovation of processed marine products (fishery).

\section{METHOD}

The method of implementing activities carried out to overcome partner problems, namely the lack of information, skills, and management in the field of innovation of processed marine products (fisheries) in empowering coastal women communities are as follows:

\section{Identification Stage}

At this stage, a theoretical study is carried out on how to empower the coastal community of the Pusong Lama village through the innovation of processed marine products and the initiation of work programs based on a location survey with the village community. 


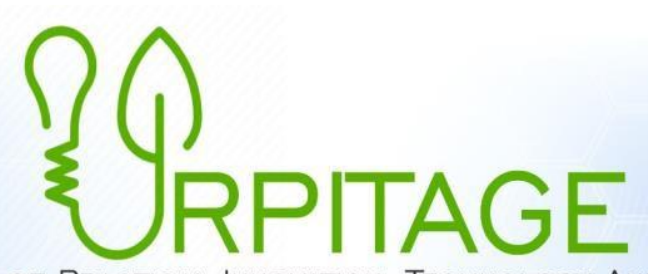

INTERNATIONAL REVIEW OF PRACTICAL INNOVATION, TECHNOLOGY AND GREEN ENERGY

2. Partner Selection Stage

At this stage, the selection of partners is carried out, namely the women (fishermen) from the coastal village of Pusong Lama considering that these women have the potential to improve the economic conditions of their families.

3. Training Stage

At this stage, training is carried out. The training will be carried out for 1 day with a workshop method where the service team implements the theories and concepts as well as practices in the innovation of processed marine products (fishery) and product packaging. The materials in this training include (1) the importance of introducing modern fish-based products without using sophisticated equipment. The goal is for partners to know the types of products that can be processed from fish raw materials. (2) training on product manufacturing, so that partners immediately know the next processing process (3) training on good and attractive packaging techniques and methods so that partners' products can be marketed and sold in the market, of course.

\section{RESULTS}

\section{Implementation of Activities and Results}

In order to solve the problems faced by mothers In the Pusong Lama village, the Community Service implementation team held a community empowerment training for coastal women in Pusong Lama Village which was held on Monday, November 22, 2021. This activity emphasized a practical learning model based on interactive and fun activities.

This activity is carried out in several sessions as follows:

\section{Opening Session}

This session begins with the opening of the members of the implementing team, followed by remarks from the Chief Executive of Community Service:

Figure 1. Message from the Chief Executive of Community Service
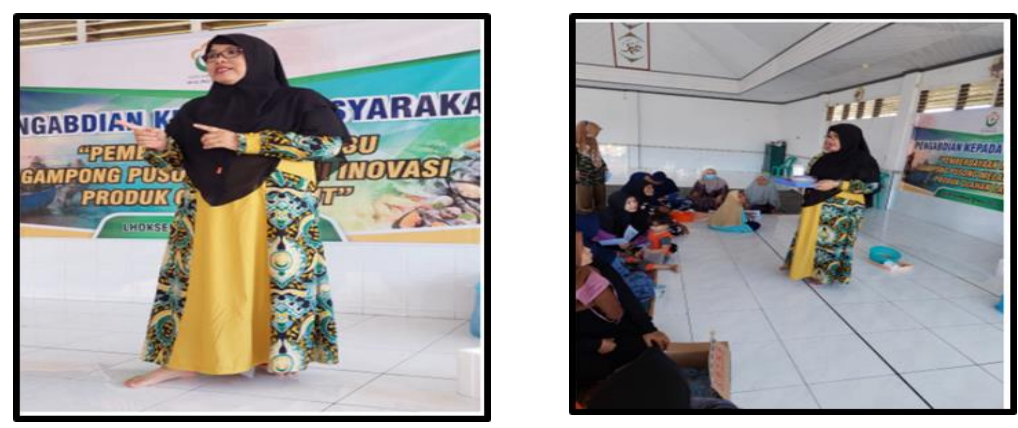

\section{Material Session}

Submission of material is done briefly. Submission of material is carried out by:

a. Likdanawati, SE, M.Si discussed the importance of increasing knowledge and skills

b. Hamdiah, SE, M.Si discusses product marketing management related to packaging

c. Cut Putri Mellita Sari, SE., M.Si discusses the variety of natural resources (sea), namely fish that can be used in an effort to increase family income 


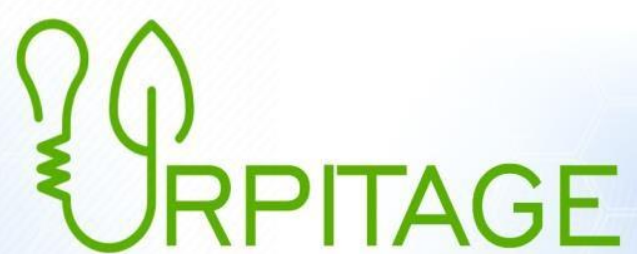

INTERNATIONAL REVIEW OF PRACTICAL INNOVATION, TECHNOLOGY AND GREEN ENERgY

Figure 2. Submission of Materials by the Implementation Team of Community Service Activities
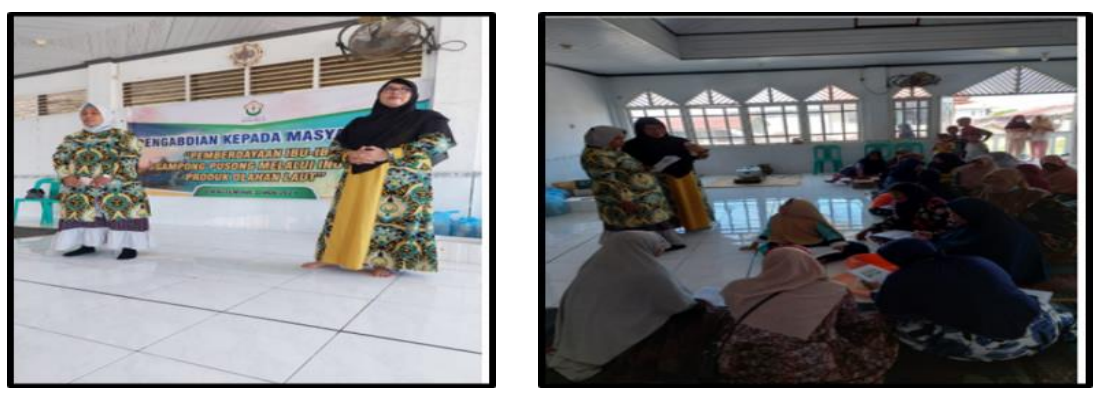

\section{Evaluation Session}

This evaluation is to see the extent of the participants' ability to process fish into food (empekempek and kemplang crackers). In this session, participants were divided into three groups. Each group makes their own empek-empek and kemplang. The results of the evaluation showed that the participants were able to process this typical Palembang food which was made from barracuda fish, pestle and cork fish.

Figure 3. Participants make their own processed seafood products (Empek-empek)
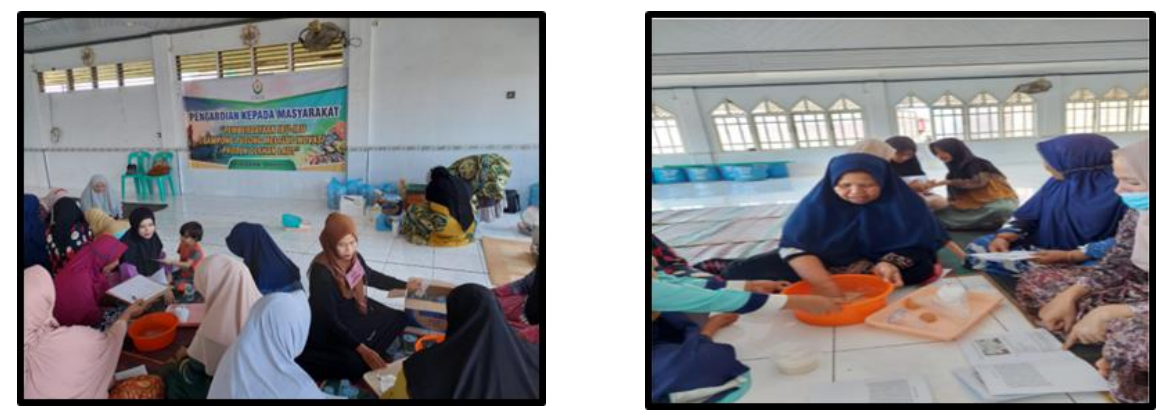

Figure 4. Processing Results of Empek-Empek
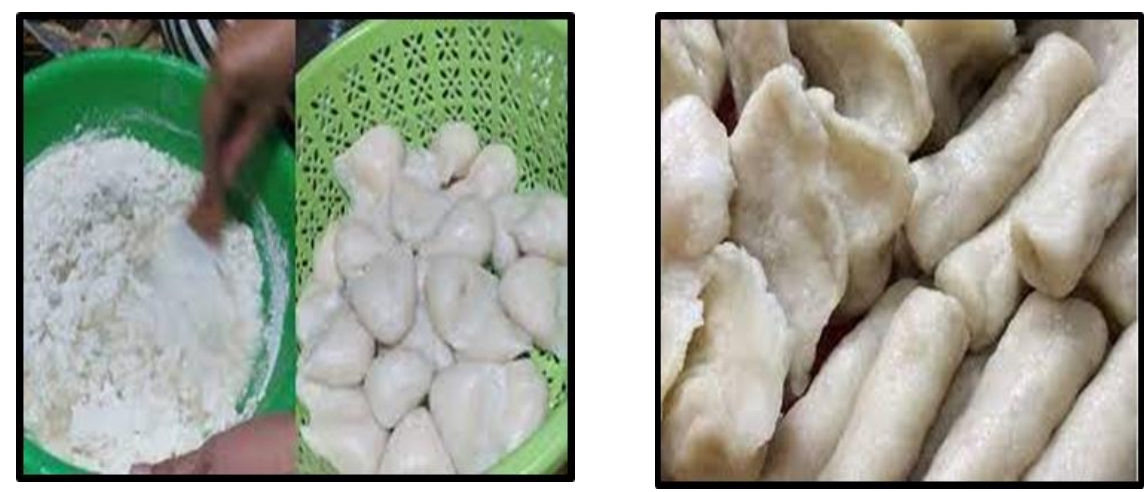

\section{Closing Session}

At the end of this session closed with a photo with the participants. The results of this activity can be described in the following indicators: 


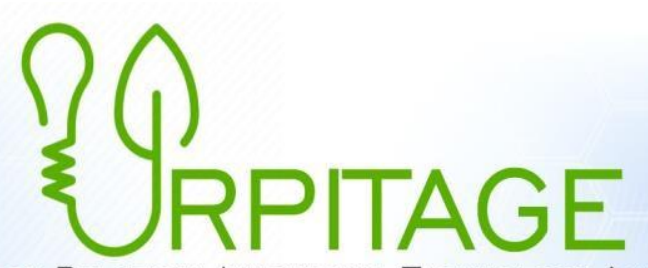

INTERnational REVIEW of PRACTICAL INNOVATION, TECHNOLOGY AND GREEN ENERgy

1. Participants are able to process fish into food (empek-empek and kemplang crackers)

2. Increased knowledge and skills of mothers in processing fish into soft and delicious empek-empek and keplang crackers typical of Palembang.

3. Increased ability of participants in product packaging (empek-empek and kemplang crackers).

Figure 5. Group Photo

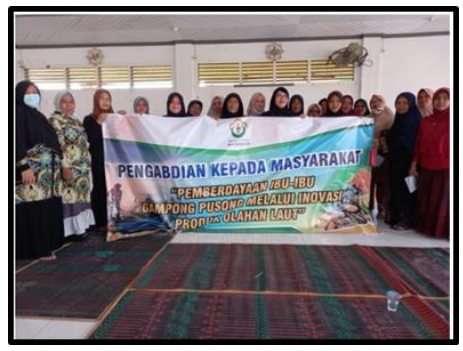

Figure 7. Packed dumplings

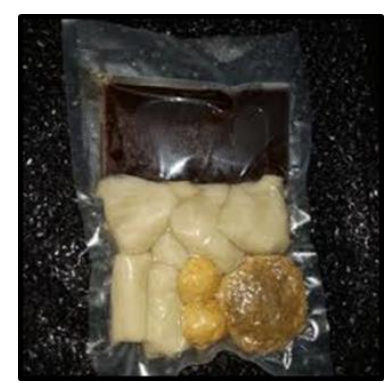

Figure 6. Kemplang crackers

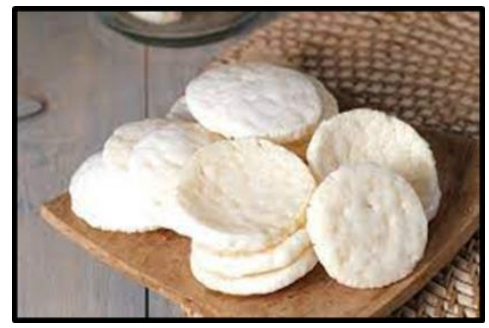

Figure 8. Packaged Kemplang Crackers

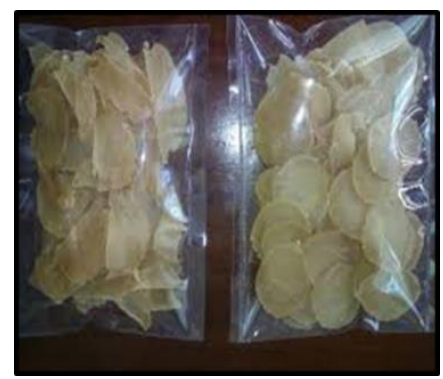

\section{Effect and Impact of Activities}

The influence and impact of activities on:

1. Partner

Increased knowledge of mothers about processing fish into empek-empek and kemplang products made from pestle or cork fish. Previously they only knew that this Palembang specialty can only be processed with the basic ingredients of mackerel fish. Mothers also understand how good packaging can be done so that it can increase total sales results. Likewise with the use of marine products, especially barracuda fish, pestle and cork.

2. College

Universities are often dubbed agents of exchange or change agents who can change the surrounding community for the better.Community dedication. As the third dharma of higher education, it is the hallmark of the higher education system in Indonesia. With this character, all elements in college should not be preoccupied with taking care of themselves. However, there must also be a caring attitude towards the conditions and realities of society. The success of the campus is not only seen from the science and technology that is growing rapidly on campus. However, it is also seen how far technology and science can be applied to society. The community feels the benefits so that it improves the standard of living of the community itself. The community service carried out has made a real contribution in developing and building the community, on the one hand, not only improving the standard of 


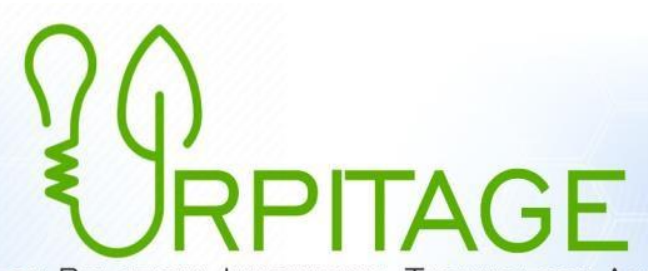

INTERnational REVIEW of PRACTICAL INNOVATION, TECHNOLOGY AND GREEN ENERgy

living of the community through the transfer of technology from the campus to the community. But on the other hand, it will also have an effect on the bargaining position of the Indonesian people in terms of the higher education system in the international world.

3. Implementing Team

Community service itself is a process of implementing science, technology, and cultural arts directly to the community using scientific methodologies as the spread of the Tri Dharma. Through this community service, lecturers have the opportunity to be able to apply their knowledge directly. Starting with giving directions, or socializing so that the public knows the technology and science delivered by the lecturer. Then together with the community it began to be implemented.

\section{Out of Devotion}

The output of this service activity is an increase in the knowledge of the women of Gampong Pusong Lama in the processing of soft and delicious empek-empek and kemplang made from barracuda fish, pestle or cork fish and also attractive packaging of empek-empek and kemplang. In addition, the output produced is in the form of publication of activities in local journals and online media.

\section{CONCLUSION}

Service activities that have been carried out in the form of community empowerment training for coastal women in the village of Pusong Lama through innovation of processed marine products which include a brief explanation of the basic raw materials used to make empek-empek and kemplang, not only using mackerel but also barracuda fish, pestle Pestle or cork fish, which are much cheaper than mackerel, processing and packaging techniques for products. Where in this service we help partners (mothers) as a solution to the problems faced, namely the lack of knowledge of processing and packaging techniques for empek-empek as well as kemplang. It is hoped that the service activities that we do can increase the knowledge and family income of our partners.

\section{REFERENCE}

Asrawaty, A. (2018). Comparison of various binders and types of fish on the quality of fish nuggets. Journal of Tropical Galung, 7(1), 33-45.

Ministry of National Education. 2003. Big Indonesian Dictionary, Third Edition, Jakarta: Balai Pustaka Publisher

Fatmasari, Dewi. 2014. Socio-Economic and Cultural Analysis of the Coastal Community of Waruduwur Village, Mundu District, Cirebon Regency. Journal of Economics and Banking Studies, IAIN Syekh Nurjati Cirebom Vol 6, No 1 page : $144-166$

Foy, Nancy. 1994. Empowering People at Work, London: Grower Publishing Company.

Koentjaraningrat. 2009: People and Culture in Indonesia. Djambangan. Jakarta. Longman.

Pradana G W. 2013. Characteristics of amino acids and tissues of fresh and steamed barracuda fish (Sphyraena jello)

Sadan, Elisheva. 1997. Empowerment and Community Planning: Theory and Practice of PeopleFocused Social Solutions. Tel Aviv: Hakibbutz Hameuchad Publishers.in Hebrew. [e-books]. 
Usdyana, NF, Ahmad, I., \& Yusuf, M. (2018). Diversification of Oyster Mushrooms as Local Food in Women Farmers Group in Malua District, Enrekang Regency. Journal of Community Dedication, 1(2), 59-68. 


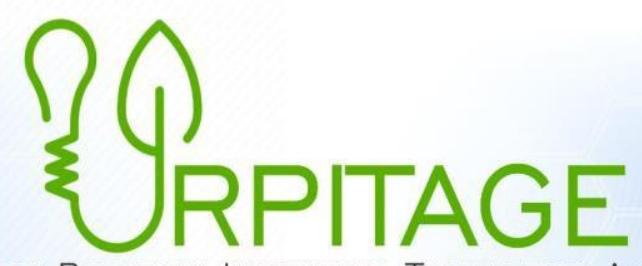

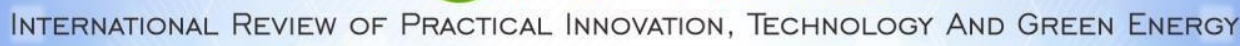

